\title{
Ethnologies
}

\section{Ethnology Museums}

New Challenges and New Directions

\section{Laurier Turgeon et Élise Dubuc}

Volume 24, numéro 2, 2002

Musées

Museums

URI : https://id.erudit.org/iderudit/006637ar

DOI : https://doi.org/10.7202/006637ar

Aller au sommaire du numéro

Éditeur(s)

Association Canadienne d'Ethnologie et de Folklore

ISSN

1481-5974 (imprimé)

1708-0401 (numérique)

Découvrir la revue

Citer cet article

Turgeon, L. \& Dubuc, É. (2002). Ethnology Museums: New Challenges and New Directions. Ethnologies, 24(2), 19-32. https://doi.org/10.7202/006637ar

Ce document est protégé par la loi sur le droit d'auteur. L'utilisation des services d'Érudit (y compris la reproduction) est assujettie à sa politique d'utilisation que vous pouvez consulter en ligne.

https://apropos.erudit.org/fr/usagers/politique-dutilisation/
Cet article est diffusé et préservé par Érudit.

Érudit est un consortium interuniversitaire sans but lucratif composé de l’Université de Montréal, l'Université Laval et l'Université du Québec à Montréal. Il a pour mission la promotion et la valorisation de la recherche. https://www.erudit.org/fr/ 


\title{
ETHNOLOGy Museums
}

New Challenges and New Directions ${ }^{1}$

\author{
Laurier Turgeon \\ CÉLAT and History Department, Université Laval \\ Élise Dubuc \\ CÉLAT, Université Laval
}

Ethnology museums are developing and spreading at a striking rate in Quebec and in the rest of Canada, in First World countries as well as in the Third World. In Canada, the number of museums has increased considerably over the last 30 years. There are currently over 1,300 museums in the country visited by some 26 million people annually. The temples of post-modern times, museums pop up as churches once did in our $19^{\text {th }}$ century cities and countryside. States, provinces, regions, cities and even the smallest towns want a museum to call their own in the hope that it will help enhance their historical memory, negotiate new alliances and affirm their identity, in short, secure their existence in the world. Just as in another era a village or an urban neighborhood without a church was marginal in a community of believers, today a population without a museum is deprived of the sense of cultural belonging created by a public place. In other words, existing beyond the reaches of tourist-inspired cultural awareness is tantamount to existing without recognition. In response to this social demand,

1. Several of the articles published in this thematic issue of Ethnologies were first presented as papers at he conference entitled "The Representations of Self and Other in Museums," organized by Laurier Turgeon and Élise Dubuc and held at Quebec City's Museum of Civilisation on February 19-20, 2002. The conference wad generously supported by The Self and the Other, project directed by Pierre Ouellet and funded by the Social Sciences and Research Council of Canada (Major Collaborative Research Initiative Program), as well as the Interculturation and Creolization project, directed by Laurier Turgeon and funded by the Fonds québécois de recherche sur la société et la culture (Collaborative Research Program). 
governments create subsidy programs to fund the growing number of museums, and universities develop training programs in museology to provide the needed skilled labor. More and more often, ethnology students are turning to museums as a principal outlet on the job market. How can this dizzying growth of museums be explained? What is the meaning of the institution's importance in the new political economy of our post-modern and post-colonial world?

This generally positive assessment should not conceal the serious problems that ethnology museums are currently experiencing. Curators warn of the difficulties that lie ahead. Some wonder whether ethnology museums have already seen their golden age and whether they will not disappear altogether (Halpin and Ames 1999; Hudson 1991). Others think that ethnology museums have become simply places of memory, void of meaning and out of sync with their initial mission; therefore it would be better to burn them all down (Galinier and Molinié 1998; Gonseth, Hainard and Kaehr 2002; Jamin 1998). This is especially the case for ethnology museums of the old colonial powers of Europe France, England, Holland, Belgium, Spain, Portugal — which sought to solidify and reinforce links with their colonies. With the decline of colonialism, these institutions have become simple warehouses for collections of assorted objects stripped of all representational power and remain of little interest to anyone. On the other hand, museums in countries born of colonization - nations where heirs of the colonizers and the colonized still live side by side - suffer the ill effects of there being too many contending interests and the negative impact of disputes of all kinds. In Canada, as in the United States and Australia, Aboriginal peoples call the authority of museums into question, demanding a say in the presentation of native objects, and sometimes the repatriation of their collections (Jones 1996; Mauzé 2001; Parezo 1998; Peers 2000; Simpson 1996; Dubuc 2002). In these "new" countries, members of socalled cultural communities also want access to museums in order to be recognized and appreciated within the heart of the nation. How can the discourse of the colonizer and the colonized or the viewpoint of the ethnographer and the "ethnographed" coexist in one space? In our increasingly pluralistic societies, how can national museums bring together the inevitably divergent interests of the different groups that make up the nation?

Not all ethnographic museums are cast from the same mould. The great diversity of their missions, and of their challenges, must be 
acknowledged. A first distinction can be made between institutions that are often labelled ethnology museums, containing collections derived from colonized peoples and treating their subjects as the "Distant Other," and those popular culture museums concerned with the "Near Other" of regional or national cultures. Suffering from complete indifference or from politicized excess, the first kind of museum seeks a new vocation by dealing with contemporary and controversial social problems such as famine, feminism, sexual identity, drugs, colonialism, war, or even museum practices themselves. Such is the case of the Neuchatel Museum of Ethnography in Switzerland that has experienced phenomenal success in the past 20 years. The brand-new Museum of Civilisation in Quebec City, which was inaugurated in 1989, has also turned to exploring contemporary issues with just as much success. On the other hand, museums of popular culture face many difficulties. After experiencing a period of glory following its founding in 1970, the Museum of Arts and Popular Traditions in Paris has stagnated. Today, planners foresee converting this institution into a museum of the Mediterranean world and moving it to Marseilles. The Museum of Arts and Popular Tradition in Trois-Rivières, Quebec, was closed two years after its 1996 opening due to a lack of funds and visitors. The new administration wishes to create a museum modelled after Quebec City's Museum of Civilisation that focuses on contemporary social issues. Don't these few examples illustrate that museums that bring us back to our roots, to our popular culture, in short, to an identity constructed around the self, no longer attract anyone? However, the Romanian Peasant Museum in Bucharest, essentially an arts and popular traditions museum, has become the most esteemed and most visited museum in Romania since the fall of Communism. Re-directing attention to rural roots and peasant culture is certainly a way of evading the still present memory of Communism and Ceaucescu's dictatorship. It is a means of transcending this traumatic period in history to start afresh, from a new base, thus reestablishing the national identity prior to the destabilizing experience of Communism. Does this example not reveal the special attention that must be paid to context? The very particular socio-political situation of post-colonial Eastern Europe gives rise to a different set of questions than that of the Western world.

The museum itself has been transformed considerably since the beginning of the $20^{\text {th }}$ century. For a long time, museums prioritized the building of collections, as well as their conservation and analysis, by 
important teams of ethnologists, anthropologists, archeologists and art historians who were all permanently affiliated with the institution. Research played an important role, and, generally speaking, permanent exhibits sought to transmit new knowledge based on the museum's collections (Sturtevant 1969). During the second half of the $20^{\text {th }}$ century, however, exhibiting began to take precedence over research, just as exhibit managers did over researchers, who progressively abandoned museums for the universities. Destined to distract as much as to instruct, exhibits are now conceived around contemporary social themes capable of attracting crowds, much like a commodity aimed at mass consumption (Terrel 1991). The way in which these current issues are explored often leads to protests, controversies and disputes that must be refereed. Thus, museum curators devote more and more time to conflict arbitration and less to producing new scientific knowledge. Displays are created with borrowed objects or with imitations, and not necessarily with those of the collection. Research is often assigned to academics who are paid per project on a freelance basis. The restoration and conservation of objects is no longer carried out by the museum, but rather by specialized organizations such as the Canadian Conservation Centre in Ottawa or the Quebec Conservation Centre in Quebec City. Like merchandise, the exhibit must circulate and is shown for relatively short periods several months at the most - thus illustrating a well -known characteristic of modern consumption: the aesthetic of the ephemeral (Appadurai 1996: 84). As James Clifford has pointed out, "museums that once articulated the cultural core or the high ground now appear as sites of passage and contestation" (Clifford 1997: 210). Do exhibits offer visitors simple products to consume in an institution governed by a market economy? If this is the case, why then doesn't the visitor passively consume the product? Why do exhibits provoke such lively reactions and fierce controversies?

Isn't the very authority of the museum itself threatened? What is certain is that the museum is under continuous scrutiny by museologists and ethnologists, as well as by journalists, politicians, vendors of art objects and artists. Its role in the production of knowledge has changed. Traditionally, museum curators and researchers have defined the areas of research, collecting objects and knowledge that they brought back to the institution to be analyzed, classified and exhibited. The museum was the boundary between the exterior space of the field, where knowledge was gathered, and the interior one of the museum, the site 
where ethnographic knowledge was (re)produced. Today this trend has been reversed as researchers migrate to universities. Now on the outside, they view the museum from a distance. With a false claim to reflexivity, anthropologists and ethnologists even propose to make the museum itself the field for observing new social practices (Handler 1993). They imagine studying the museum as a contact zone, as a space of identity negotiation, as a place where rites of passage and new social hierarchies will be instituted (Clifford 1997). The visitor becomes a substitute for the informant. The observer becomes the observed. For the museum institution, what is the meaning of this passage from a place of observation to a place where one is observed? Does this indicate that the museum has lost its power to create new knowledge? Is the ethnologist reappropriating this once abandoned territory?

Another way of apprehending the museum as a field of study is through the history of the museum and its collections. Several approaches have been attempted. The most widespread of these is the history of the museum itself, used to identify similarities and singularities, to understand administrative workings and to trace the evolution of the institution (Ames 1992; Barringer and Flynn 1998; Bennett 1995; Pearce 1999; Stocking 1985). Another approach is to begin by the history of collectors and their collections since most museums originated from private collections (Baudrillard 1968; Krech et Hail 1999; Pomian 1987; Pearce 1995, 1998; Poulot 2002). Recounting the collector's biography allows for an understanding of the logic behind the collection and makes it possible to see to which point the collection is an incarnation and projection of the collector, the founder who transforms chaotic matter into an ordered and meaningful system. By taking possession of objects and elaborating complete series, the collector is transported outside himself and projected into a social world. A third approach consists of studying the object itself and its displacement in time and in space (Appadurai 1986; Feest 1998; Meyers 2001; Thomas 1991; Turgeon 1997). Studying the movement of objects from one individual to another, from one culture to another, by way of exchange (as much inside the museum as out of it) offers the possibility of better understanding the social life of objects: rituals of possession and depossession, changes undergone during cultural recontextualization and transformations of meaning. Breaking with this trend that stresses the relationship between objects and humans or material culture and social life, some have turned their attention to the object's materiality 
in order to see how abstract notions such as nation, desire and sacrifice are made tangible in matter (Bazin et Bensa 1994; Miller 1998). Is it necessary to choose between being interested in the socialization of objects and the materialization of social relationships? Is it really possible to find transcendent structures of consciousness in materiality? Aren't these different approaches complementary?

Ethnologists, museologists and vendors tend to attach more value to "authentic objects." Although the notion of authenticity is relative, it generally signifies an object produced by local artisans and conserved in its original state. We would not be inclined to collect or exhibit an ethnographic object coming from another group and acquired in an exchange. Even less importance would be given to a hybrid object made up of a mix of Native and Western elements. Ethnologists generally consider these fusions as a sign of assimilation and as the beginning of cultural decline (Muller 1999). However, what ethnologists interpret as a loss of tradition is often for Natives a stimulating and dynamic change in fashion. Furthermore, an object judged "hybrid" by Western ethnologists or museologists can be completely integrated into the host culture and judged authentic by indigenous peoples (Clifford 1997: 161). In reality, an object can be considered authentic at several stages of its existence according to the groups or individuals that own it. Rather than fixate on authenticity, would it not be better to attempt to understand the process of making objects authentic or inauthentic? Don't indigenous groups produce their own fusion of tradition and modernity? Why must we always return to the material object to understand authenticity? Wouldn't photos of the object's use in its original context be more evocative of the first meaning given to the object?

There is no doubt that North American ethnology museums housing Amerindian collections have reached a turning point in the past twenty years. Protests by various Indian groups have impacted on the managing and exhibiting of these collections. In Canada, the Cree boycott of The Spirit Sings exhibit at the Glenbow Museum in Calgary, opened during the 1989 winter Olympic Games, had international repercussions. At home, it forced the Canadian government to assemble a task force composed of members of the Assembly of First Nations (a national Amerindian association) and the Canadian Museums Association. Tabled in 1992, their report proposed measures designed to include Natives in each step of the collection's management and to construct a 
new museum partnership between Native and Euro Canadians. Though not a legal document, the report nonetheless created a new consensus and a shared responsibility for First Nations' collections. In the United States, legal measures were taken in the form of the Native American Graves Protection and Repatriation Act (NAGPRA). This legislation gave Native communities the right to repossess human bones and associated objects from state museums. Far from destructive, the new legal strictures led museum curators to inventory their ethnographic collections, to become better acquainted with their contents and to establish direct contacts with those who had previously owned them (Mihesuah 2000). Moreover, the repatriation of collections gave American Natives an occasion to heal from colonial insults, to reinstate a collective memory of their past, to restore awareness of their identity, to create their own museums and to renew their relationship with Whites (Ames 1999; Mauzé 1999, 2001). An in-depth study of the effects of this repatriation is an important next step in evaluating to what extent the reclamation of material objects is in fact a prolongation of the exchanges and negotiations between Natives and Whites.

These considerations lead us to reflect upon the notion of the past as well as our relationship with the other. Ethnographic collections are at the heart of tensions involving colonialism and nationalism. To whom does the past belong? Who has the right to speak about whom? And on behalf of what? These are some of the questions that the authors of this thematic issue about ethnographic museums are trying to answer, each from the perspective of his or her field of specialization. The time has come to ask certain probing questions: a number of ideas, conventions and practices are examined and redefined in these texts.

First of all, the notion of ethnographic collections must be clarified. This notion is historically loaded and embraces various realities; currently it creates confusion. In an article providing a renewed approach to collections, Miriam Clavir states from the beginning that the term "ethnographic" contains a paradox. On the one hand, this term restricts a body of material, that of the other. Aboriginal collections are thus relegated to a sector of knowledge, to a university discipline, to a methodology (i.e. fieldwork), even to a specific type of museum institution: the ethnographic museum. Such collections thus artificially create a split between the useful and the pleasant, between the functional and the beautiful, to mention only these few aspects. We can add here that such meaning can also be applied to collections coming from the 
rural and working classes. Always reflected is a lack of equilibrium as concerns the authority of discourse between people from western countries and those they colonized, between the urban educated and others. At the same time, the term "ethnographic" points to an opening to the other which is given concrete form when a more equal partnership is established. This approach, taken more often than ever before, at least in North America, leads us to consider the various ways in which the notion of heritage is perceived, as well as the cultural variations of its definition and how every society deals with the matter itself.

Yves Bergeron suggests that we take a retrospective look at Québec's experience of cultural heritage and the very particular way in which this experience has been given concrete form through its museums. The author underscores the significance of the French connection (of which thinkers like Georges-Henri Rivière remain important figures) and its extensive influence as concerns the creation of museum institutions in the field of ethnology. He observes, however, that a new model is emerging, in spite of the current crisis experienced by the latter institutions, particularly in the past ten years or so, that of museums of society; furthermore, he emphasizes the leading role played by Quebec City's Museum of Civilisation in this area.

The relationship between the self and the other appears as a backdrop in all the texts proposed. In their Coverdale-collection studies, Nathalie Hamel and Andrée Gendreau's articles make this relationship abundantly clear. This important collection for the history of museology in Quebec is available in two main parts, the Americana and the Canadiana, to which the art collection can be added; these are two prisms through which Native people and the rural classes have been stereotyped by the vision of a passionate collector, a business person influenced by the imperatives of the tourist industry. Nathalie Hamel's in-depth study of the Coverdale Amerindian collections deals with detail and context. Paying close attention to such matters enables research to advance and allows us to break the vicious circle of writers repeatedly quoting other writers, who in turn quote others. Previously unpublished data taken from primary archival sources reveal an unknown aspect of this important collection. Hamel wonders what cultural consequences such a heritage could have on the collective heritage of a society, most notably as concerns our current perception of Native cultures and how they are exhibited. In the same vein, but this time examining traditional Quebec society, Andrée Gendreau is interested in the construction of 
the self through the other's perception of us. By inverting the perspective, she emphasizes the importance of place of presentation in relation to the social classes and cultural groups thus exhibited. The Coverdale iconographic collections were displayed on the walls of the Manoir Richelieu, a luxury hotel in Charlevoix; the characteristically FrenchCanadian "habitant-style" furniture was used to furnish the Tadoussac Hotel located at the mouth of the Saguenay River; and the Amerindian objects were exhibited in a little house next to a reconstruction of what many agree may have been one of the first trading posts in Canada. Both Hamel and Gendreau place emphasis on the avatars of defining the self through the other, whether the other has been exotic, as seen through the Americana collections, or archaic, as witnessed in the Canadiana collections.

Museums in general, and ethnographic museums in particular, are places where the majority group's limits of tolerance for various minority groups are measured. Reesa Greenberg's article takes us into the subtleties of the relationship between views of the self and views of the other, but this time as seen from the inside. She urges us to stay away from definitions that are too simplistic and explanations that are superficial or dualistic as concerns the self and the other. Using a study involving a specific phenomenon, that of European museums concerning Jews, the author takes the questioning process to a general level which could easily apply to all museums. The drama of genocide and the unresolved problems pertaining to the Holocaust are presented here as an epiphenomenon of a larger commemoration movement that is more and more part of the representation parameters of museums the world over. It is still important to take into account that the general experience of museum goers and the emotional depth of their experience, along with their level of tolerance, are an integral part of the overall considerations concerning the national and regional histories of the various countries where a given representation takes root.

Also by means of a case study, in their article Daniel Arsenault and Louis Gagnon deal with the question of place as a paradigm for the museum experience. They clearly show how difficult it is to reconcile the points of view of scientists, tourists and Native communities. Is cultural heritage a source of wealth waiting, as it were, to be mined? By whom and for whose benefit exactly? Such questions are open to discussion. They enable the authors to deal with a set of themes which are useful in relation to a more general reflection on the challenges of 
"highlighting" Native cultural heritage. The issues raised - taking advantage of natural and cultural landscapes (and notably the subject of shamanism) - clearly reflect the temptation to draw upon "eco" and "ethno" tourism potential as well as the pitfalls of the New Age era. The interests of the different groups are balanced between potentiality and on-site concerns which entirely correspond to those of our era.

In her study of ethnographic museums in Croatia, Nadia GuzinLukic deals with the theme of place, the anchor point for museum activity. By focusing on traditional costume, religious customs and rural folklife, the museum offers "a scientific authentification to a culture anchored in the soil and the blood of the people who inhabit it." Likewise, Philippe Dubé deals with the ways in which the museum territorializes culture, but in this case from the point of view of museology in the regions of Quebec. Incorporating the work carried out by his Université Laval Museology Research-Action Group, the author uses its initiatives in the Saguenay-Lac-Saint-Jean and Kamouraska regions to provide a perspective as concerns the direct participation of actors from the region and the networking possibilities of concerned institutions. Dubé underscores, and rightly so, the critical situation of so-called peripheral museums, neglected by large urban centres and forgotten by government authorities, and sees this crucial step as a multi-faceted opportunity for development, provided of course that the proposed cultural action is taken into account.

Élisabeth Kaine's article takes on the characteristics of a personal testimony where the entire emphasis is on the process of establishing contact among the different identities in question. This professor of design from the Université du Québec à Chicoutimi — she is Métis herself, with an Irish father and a Wendat mother - presents various aspects of an approach she has been developing for a long time; her ideas are presented in the form of a "life story" (an approach with which we are very familiar in ethnology). The "design and material culture" project should be promoted in museum circles, as much for its concrete achievements as for the philosophic questions it raises. The project deals with the reactivation of objects from the past in contemporary practices. By challenging modern-design practices, Kaine conveys the basic principles underlying her project, drawn from sources of tradition and resolutely turned toward creative development. Her professional 
experiences with Inuit and Innu communities lead us to qualify the whole notion of the museum and its usefulness in Native communities.

Two examples of setting up museums in France provide an interesting contrast. For instance, it is interesting to look at the renovation project undertaken by the Lyon Natural History Museum and its director, Michel Côté, especially since this project can be seen as a sort of inverted criss-cross. Would it be possible to export the new Quebec museology to France once the French model has been incorporated into its practices? This is the question we must ask ourselves as we take note of proposals for a networking approach "based on complementarity and reinforcement of cultural actions," as stipulated by the long-time director of research and important player from Quebec City's Museum of Civilisation. The "Museum of Confluence" and the "Museum of World Cultures" provide us here with two different poles — science and society - and turn the museum institution into a social actor dedicated to its public. The fact of its questioning copyrights (or further still the repatriation of collections) already indicates a detachment on the part of the institution from the sacred relationship which traditionally linked it to the material expression of culture. New museums are being set up in France in line with established traditions, but an attempt is nevertheless being made to redefine the vocation of the institution. For example, Emmanuel Désveaux, director of research and education project of the new Quai Branly Museum, an institution created from the ashes of the Museum of Human Heritage and the Museum of African and Oceanic Arts, pays particular attention to the renewal of museographical presentation. Having inherited outdated practices, such as dioramas and even human zoos, the Quai Branly, following the model provided by the Canadian Museum of Civilisation in Gatineau, has developed new practices in order to break with evolutionism. Désveaux is conscious of the need to invent a new museography and proposes to carry out a critical evaluation of collection enhancement since the $18^{\text {th }}$ century as well as to develop new perspectives for categorising and exhibiting objects. He clearly states his concern with avoiding the pitfalls of fiction, as well as those of the market, issues new institutions simply cannot ignore. 


\section{References}

Ames, Michael M. 1992. Cannibal Tours and Glass Boxes. The Anthropology of Museums, Vancouver: University of British Columbia Press.

- 1999. "How to Decorate a House: The Re-Negociation of Cultural Representations at the University of British Columbia Museum of Anthropology". Museum Anthropology, (22) 3: 41-51. Appadurai, Arjun. 1986. The Social Life of Things: Commodities in Cultural Perspective. Cambridge: Cambridge University Press.

- 1996. Modernity at Large: Cultural Dimensions of Globalization. Minneapolis: University of Minnesota Press.

Barringer, Tim and Tom Flynn (eds.). 1998. Colonialism and the Object.

Empire, Material Culture and the Museum. New York: Rouledge.

Baudrillard, Jean. 1968. Le système des objets. Paris: Denoël / Gonthier. Bazin, Jean and Alban Bensa. 1994. "Des objets à la chose". Genèses 17: 4-7.

Bennett, Tony. 1995. The Birth of the Museum: History, Theory, Politics.

New York: Routledge.

Clifford, James. 1997. Routes: Travel and Translation in the Late Twentieth Century. Cambridge (Mass.): Harvard University Press.

Dubuc, Élise. 2002. "Entre l'art et l'autre, l'émergence du sujet". In Gonseth, Marc-Olivier, Jacques Hainard and Roland Kaehr (eds.), Le Musée cannibale. Neuchâtel, Musée d'ethnographie : 31-58.

Feest, Christian. 1998. "Transformations of a Mask: Confidential Intelligence from the Lifeway of Things". Baessler-Archiv (Berlin): 255-293.

Galinier, Jacques and Antoinette Molinié. 1998. "Le crépuscule des lieux: mort et renaissance du musée d'ethnographie". Gradhiva 24: 93-102.

Gonseth, Marc-Olivier, Jacques Hainard and Roland Kaehr. 2002. "Le Musée cannibale". In Gonseth, Marc-Olivier, Jacques Hainard et Roland Kaehr (eds.), Le Musée cannibale. Neuchâtel, Musée d'ethnographie: 9-14.

Halpin, Marjorie M. and Michael M. Ames. 1999. "Musées et Premières Nations au Canada”. Ethnologie française 29: 431-436.

Handler, Richard. 1993. "An Anthropological Definition of the Museum and Its Purpose". Museum Anthropology 17-1: 33-36.

Hudson, Kenneth. 1991. "How Misleading Does an Ethnographical Museum Have to Be?" In Karp, Ivan and Steven D. Lavine (eds.), Exhibiting Cultures: The Poetics and Politics of Museum Display. Washington, Smithsonian Institution Press: 457-464. 
Jamin, Jean. 1998. "Faut-il brûler les musées d'ethnologie?" Gradhiva 24: 65-69.

Jones, Anna Laura. 1993. "Exploding Canons: The Anthropology of Museums". Annual Review of Anthropology 22: 201-220

Karp, Ivan and Steven D. Lavine (eds). 1991. Exhibiting Cultures: The Poetics and Politics of Museum Display. Washington: Smithsonian Institution Press.

Krech, Sheppard and Barbara A. Hail (eds.). 1999. Collecting Native America, 1870-1960. Washington: Smithsonian Institution Press.

Mauvé, Marie. 1999. "Un patrimoine, deux musées: la restitution de la Potlatch Collection”. Ethnologie française 29: 419-430.

2001. "Collectes, collecteurs, collections (Amérique du Nord)". Gradhiva 29: 59-61.

Meyers, Fred R. 2001. The Empire of Things: Regimes of Value and Material Culture. Santa Fe: School of American Research Press.

Mihesuah, Devon A. 2000. Repatriation Reader. Who Owns American Indian Remains? Lincoln: University of Nebraska Press.

Miller, Daniel. 1998. "Why some things matter". In Daniel Miller (ed.), Material Cultures. Chicago, University of Chicago Press: 3-21.

Muller, Jean-Claude. 1999. "Sous le masque africain, quelques fauxsemblants". In Gonseth, Marc-Olivier, Jacques Hainard et Roland Kaehr (eds.), L'art c'est l'art. Neuchâtel, Musée d'ethnographie: $45-$ 60.

Nicks, Trudy and Tom Hill. 1992. Turning the Page: Forging New Partnerships Between Museums and First Peoples. Ottawa, Assembly of First Nations/Canadian Museums Association.

Pearce, Susan M. 1995. On Collecting: An Investigation into Collecting in the European Tradition. New York: Routledge.

1998. Collecting in Contemporary Practice. Londres: Sage.

.1999. "Museums of Anthropology or Museums as Anthropology". Anthropologica 41-1: 25-34.

Parezo, Nancy. 1998. "The Formation of Anthropological Archival Records". In David Kingery (ed.), Learning From Things: Method and Theory of Material Culture Studies. Washington, Smithsonian Institution Press: 145-174.

Peers, Laura. 2000. "Native Americans in Museums". Anthropology Today 16-6: 8-13.

Pomian, Krzysztof. 1987. Collectionneurs, amateurs et curieux. Paris: Gallimard. 
Poulot, Dominique. 2002. "Musées et expositions des origines à nos jours". Sciences humaines (hors-série 37): 52-5.

Simpson, Moira. 1996. Making Representations: Museums in the PostColonial Era. London/New-York: Routledge.

Sturtevant William C. 1969. "Does Anthropology Need Museums?" Proceedings of the Biological Society of Washington 82: 619-650.

Terrel, John. 1991. "Disneyland and the Future of Museum Anthropology". American Anthropologist 93: 149-153.

Stocking, George (ed.). 1985. Objects and Others: Essays on Museums and Material Culture. Madison: University of Wisconsin Press.

Thomas, Nicholas. 1991. Entangled Objects: Exchange, Material Culture and Colonialism in the Pacific. Cambridge: Harvard University Press. Turgeon, Laurier. 1997. "The Tale of the Kettle: Odyssey of an Intercultural Object". Ethnohistory 44 (1): 1-29. 